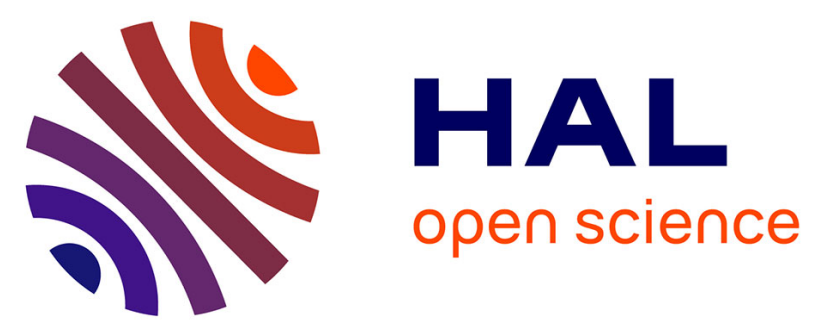

\title{
Molecular characterization of zoonotic Cryptosporidium spp. and Giardia duodenalis pathogens in Algerian sheep
}

Lynda Sahraoui, Myriam Thomas, Aurélie Chevillot, Mohamed Mammeri, Bruno Polack, Isabelle Vallée, Jérôme Follet, Hacina Ain-Baaziz, Karim Tarik Adjou

\section{- To cite this version:}

Lynda Sahraoui, Myriam Thomas, Aurélie Chevillot, Mohamed Mammeri, Bruno Polack, et al.. Molecular characterization of zoonotic Cryptosporidium spp. and Giardia duodenalis pathogens in Algerian sheep. Veterinary Parasitology: Regional Studies and Reports, 2019, 16, pp.100280. 10.1016/j.vprsr.2019.100280 . hal-03176067

\section{HAL Id: hal-03176067 \\ https://hal.inrae.fr/hal-03176067}

Submitted on 22 Oct 2021

HAL is a multi-disciplinary open access archive for the deposit and dissemination of scientific research documents, whether they are published or not. The documents may come from teaching and research institutions in France or abroad, or from public or private research centers.
L'archive ouverte pluridisciplinaire HAL, est destinée au dépôt et à la diffusion de documents scientifiques de niveau recherche, publiés ou non, émanant des établissements d'enseignement et de recherche français ou étrangers, des laboratoires publics ou privés.

\section{(ㄷ)(1) $\$$}

Distributed under a Creative Commons Attribution - NonCommercial| 4.0 International 
1 Molecular characterization of zoonotic Cryptosporidium spp and Giardia duodenalis

2 pathogens in Algerian sheep

3 Lynda Sahraoui a, b, Myriam Thomas ${ }^{\mathrm{c}}$, Aurélie Chevillot ${ }^{\mathrm{c}}$, Mohamed Mammeri ${ }^{\mathrm{a}, \mathrm{d}}$, Bruno

4 Polack $^{\text {a }}$, Isabelle Vallée ${ }^{\mathrm{c}}$, Jérôme Follet ${ }^{\text {e, f }}$, Hacina Ain-Baaziz ${ }^{\text {b }}$, Karim Tarik Adjou ${ }^{\text {a,* }}$

5 a UMR BIPAR, Ecole Nationale Vétérinaire d'Alfort, Anses, INRA, Université Paris-Est,

6 Maisons-Alfort, F-94700, France.

$7{ }^{b}$ Laboratory of Animal Health and Production, Ecole Nationale Supérieure Vétérinaire

8 (ENSV) d'Alger, Issad-Abbes Oued-Smar, Algiers, Algeria.

$9{ }^{\mathrm{c}}$ UMR BIPAR, Anses, Ecole Nationale Vétérinaire d'Alfort, INRA, University Paris-Est,

10 Animal Health Laboratory, Maisons-Alfort, F-94700, France

$11{ }^{\mathrm{d}}$ Phileo Lesaffre Animal Care, 137 rue Gabriel Péri, 59700 Marcq-en-Barœul, France.

12 e Université de Lille, CNRS, ISEN, UMR 8520- IEMN, Lille France 59000, France.

$13 \quad{ }^{\mathrm{f}}$ ISA-YNCREA Hauts de France 59046 Lille Cedex, France.

$14 *$ Corresponding author: karim.adjou@ $@$ vet-alfort.fr (K. T. Adjou, Tel: +33143967124). 
16

17

18

19

20

21

22

23

24

\section{Highlights}

- Detection of Cryptosporidium spp. and Giardia duodenalis in Algerian lambs using molecular tools.

- In lambs, C. parvum, C. ubiquitum, and Giardia duodenalis were identified.

- In lambs, subtypes identified were C. parvum IIdA16G1, IIaA21G2R1, and IIaA13G2R1.

- Assemblage E, D, and mixed Assemblage E + A of Giardia duodenalis were detected.

- Sheep might be a source for zoonotic C. parvum and G. duodenalis in Algeria. 


\section{Abstract}

Little is known about the presence of Cryptosporidium spp. and Giardia duodenalis in Algerian sheep, nor their potential role as zoonotic reservoirs. This study aimed to investigate the occurrence and distribution of these two protists in lambs. A total of 83 fecal samples were collected from lambs ( $<40$ days old) from 14 different farms. Samples were screened for Cryptosporidium spp. and Giardia duodenalis presence using immunofluorescent techniques (IF). Nested PCR of the small subunit ribosomal RNA (rRNA) gene, followed by restriction fragment length polymorphism (PCR-RFLP) and sequence analyses were used to identify Cryptosporidium species. C. parvum was further subtyped by sequencing the highly polymorphic $60 \mathrm{kDa}$ glycoprotein $(\mathrm{gp} 60)$ gene. For $G$. duodenalis, nested PCR of the glutamate dehydrogenase $(g d h)$ and triose phosphate isomerase $(t p i)$ genes was performed and then PCR-RFLP was used to identify G. duodenalis assemblages. Cryptosporidium oocysts and Giardia cysts were detected in 36/83 (43\%) and 23/83 (28\%) of fecal samples, respectively. Of the 21/36 (58\%) Cryptosporidium samples that were positive with IF, 16/21 (76\%) were identified as $C$. parvum, and 5/21 (24\%) as C. ubiquitum. From 15 C. parvum isolates, 2 subtypes were identified within the IIa subtype family, including IIaA21G2R1 (3/15) and IIaA13G2R1 (1/15), while IIdA16G1 (11/15) was the only subtype identified from the IId subtype family. Of the 16/23 (69\%) G. duodenalis IF-positive samples, the most frequent assemblage was ruminant-specific assemblage E (10/16), followed by assemblage D (4/16), and A + E mixed assemblages (2/16). This study is the first to identify and genotype both Cryptosporidium spp. and Giardia duodenalis in Algerian lambs, and is also the first to describe G. duodenalis assemblage D in small ruminants. The presence of zoonotic C. parvum subtype families (IIa, IId), C. ubiquitum, as well as G. duodenalis assemblage A+E, indicates that sheep could play an important role as a potential reservoir for protists.

Keywords: Cryptosporidium; Giardia; sheep; Algeria; genotyping; zoonosis. 


\section{Introduction}

Cryptosporidium spp. and Giardia duodenalis are common zoonotic enteric protists causing clinical and subclinical infections in farm animals worldwide, and also pose a significant threat to public health (de Graaf et al., 1999).

Clinical symptoms of Cryptosporidium infection in small ruminants (lambs and kids) include diarrhea and weight loss, which can be fatal. This not only severely impacts small ruminant farming economies, but also creates a significant transmission risk to humans (de Graaf et al., 1999). Thus far, seven Cryptosporidium species have been isolated from sheep feces, including C. parvum, C. ubiquitum, C. xiaoi, C. hominis, C. andersoni, C. fayeri, and C. suis (Paraud and Chartier, 2012).

In Algeria, sheep and goat populations are currently estimated at 28 and 4.9 million head respectively, while the cattle population is estimated at only 1.9 million head (Ministry of Agriculture and the rural development, 2016). However very little is known about which specific Cryptosporidium species/subtypes infect small ruminants in Algeria. Thus far, only a few studies have characterized Cryptosporidium at a molecular level in calves (Baroudi et al., 2017; Benhouda et al., 2017; Ouakli et al., 2018), and only one recent molecular Cryptosporidium study on sheep isolates exists (Baroudi et al., 2018). On the other hand, Giardia duodenalis is known to infect numerous mammalian species and consists of at least eight distinct genetic groups or assemblages (A to $\mathrm{H}$ ), often with different host specificities: assemblage $\mathrm{A}$ and $\mathrm{B}$ in humans, primates and other mammals; assemblage $\mathrm{C}$ and $\mathrm{D}$ in $\operatorname{dogs}$ and other canids; assemblage $\mathrm{E}$ in hoofed livestock; assemblage $\mathrm{F}$ in cats; assemblage $\mathrm{G}$ in rodents; and assemblage $\mathrm{H}$ has been reported in seals and a gull (Ballweber et al., 2010; Ryan and Cacciò, 2013). In Algeria, G. duodenalis was recently identified in calves, including 
ruminant-specific assemblage $\mathrm{E}$ and zoonotic assemblage $\mathrm{A}$ (Baroudi et al., 2017), but no data exist for small ruminants.

The farming of small ruminants is one of the main sources of meat production in Algeria and plays a vital role in food security. As stated before, there are more than 32.9 million small ruminants in Algeria; thus farming these animals can improve the living standards of farmers and households, as well as increase the general availability of animal protein for consumption, thus helping to alleviate poverty.

Little is known about the presence of Cryptosporidium spp. and Giardia duodenalis in sheep, nor the role that these animals may play as reservoirs for these parasites. Therefore, the present work aimed to identify Cryptosporidium and Giardia at a molecular level in lambs from different northern Algerian regions.

\section{Materials and Methods}

\section{Specimen collection}

Between November 2015 to March 2017, 83 randomly selected lamb rectal fecal samples were collected from 14 farms across four northern Algerian provinces located in the NorthCenter (Djelfa and Msila), North-West (Sidi Bel Abbès), and North-East (Souk Ahras) (Fig. $1)$.

The Algerian sheep population is estimated at approximately 28 million head. Sheep farming mainly occurs in northern Algeria as the southern regions (Sahara) are too arid. The sheep populations from the northern provinces included in this study represent approximately one quarter $(23 \%)$ of the total national sheep population. The farms included in this study were arbitrarily designated F1 to F14, and were predominantly extensive herds (free-ranging) (9/14) where animals graze freely during the day and are housed in sheds at night. Whereas in 
intensive herds (5/14), animals were housed in farm buildings with zero access to grazing (Table 1).

Sampled lambs were less than 40 days old, presenting with or without diarrhea. Fecal samples were individually collected from lambs in plastic boxes, and were then preserved by diluting 1:1 in $5 \%(\mathrm{wt} / \mathrm{vol})$ potassium dichromate as previously described (Bornay-Llinares et al., 1999), and conserved at $4^{\circ} \mathrm{C}$ until use.

\section{Sample processing}

All samples were concentrated from $1 \mathrm{~g}$ of original fecal matter as previously described (Castro-Hermida et al., 2005), then screened for the presence of Giardia cysts and/or Cryptosporidium oocysts by direct immunofluorescence assays (IFA) (MeriFluor ${ }^{\circledR}$ Cryptosporidium/Giardia, Meridian Bioscience Europe, Milano, Italy). Briefly, oocysts and cysts were resuspended in $500 \mu \mathrm{L}$ of PBS (phosphate buffered saline), then IFA was performed in duplicate using $20 \mu \mathrm{L}$ of this solution. Entire slides were examined under a fluorescent microscope at $400 \times$ magnification. Samples were considered to be positive when at least one Cryptosporidium oocyst or Giardia cyst was observed per slide.

\section{DNA extraction and PCR amplification}

Samples with positive IFA results for either parasite then underwent genomic DNA extraction using the QIAamp Mini Kit (Qiagen), according to manufacturer's instructions. To disrupt (oo)cyst walls, an initial step of six freeze-thaw cycles (freezing in liquid nitrogen for 5 min and thawing at $95{ }^{\circ} \mathrm{C}$ for $5 \mathrm{~min}$ ) was incorporated into the protocol.

To detect Cryptosporidium spp. in Cryptosporidium IFA-positive samples, nested PCR was used to amplify an $830 \mathrm{bp}$ fragment of the $18 \mathrm{~S}$ SSU-rRNA gene as previously described (Xiao et al., 1999). PCR products were analyzed in 2\% agarose gel stained with ethidium bromide $(0.5 \mu \mathrm{g} / \mathrm{mL})$. 
120

121

122

123

To confirm the presence of G. duodenalis in Giardia IFA-positive samples, semi-nested PCR was used to amplify the glutamate dehydrogenase $(g d h)$ gene and triose phosphate isomerase (tpi) gene. (Read et al., 2004). Amplification of a 530 bp tpi gene fragment was performed as previously described (Sulaiman et al., 2003). Reactions were then visualized on ethidium bromide-stained $(0.5 \mu \mathrm{g} / \mathrm{mL}) 2 \%$ agarose gels.

\section{PCR-RFLP}

In order to identify Cryptosporidium species, positive $18 \mathrm{~S}$ SSU-rRNA products were subjected to PCR-RFLP analysis using two endonucleases; SspI and MboII (New England BioLabs, France) as previously described (Feng et al., 2007). Digestion products were separated on 3\% MetaPhor agarose (Ozyme, France). The different Cryptosporidium species were identified according to previously described restriction patterns (Feng et al., 2007).

For G. duodenalis, positive gdh PCR products were digested with NlaIV (New England Biolabs), and tpi PCR products with DdeI (New England Biolabs). RFLP analysis to determine the assemblage was directly carried out on PCR products in a $20 \mu \mathrm{L}$ reaction volume including $10 \mu \mathrm{L}$ of unpurified PCR product, $7.6 \mu \mathrm{L}$ sterile water, $0.4 \mu \mathrm{L}$ restriction enzyme, and $2 \mu \mathrm{L} 10 \mathrm{X}$ restriction enzyme buffer. Digestions were incubated at $37^{\circ} \mathrm{C}$ for 3 or $4 \mathrm{~h}$, for $g d h$ and tpi respectively. Restricted fragments were separated and visualized by electrophoresis on 2\% high-resolution grade agarose gel (MetaPhor) stained with ethidium bromide $(0.5 \mu \mathrm{g} / \mathrm{mL})$. A 50 bp DNA ladder $\left(\mathrm{GeneRuler}^{\mathrm{TM}}\right.$, Thermo Scientific $\left.{ }^{\mathrm{TM}}\right)$ was used as a size marker. The genetic assemblages were differentiated according to previously described restriction patterns (Read et al., 2004; Sulaiman et al., 2003).

gp60 gene analysis for $C$. parvum subtyping

C. parvum samples were subtyped by nested PCR-sequence analysis of the $60 \mathrm{kDa}$ glycoprotein locus (gp60), and all positive isolates were sequenced as previously described 
144 (Gatei et al., 2006). Briefly, the PCR products were sent to Genoscreen (Lille, France), and 145 sequenced in both directions. Consensus sequences were obtained using BioEdit software 146 (version 5.0.6). The C. parvum subtypes were named using the recommended nomenclature 147 system (Sulaiman et al., 2005; Xiao, 2010). The nucleotide sequences obtained from 15 148 isolates were deposed to GeneBank database under access number from: MK453405 to 149 MK453419.

150

151

152

153

154

155

156

157

158

159

160

161

162

163

164

165

166

167

\section{Results}

Results from this study are summarized in Table 1.

\subsection{Cryptosporidium species and subtype occurrence according to age and diarrhea} status

Cryptosporidium spp. were detected by IFA in 36/83 (43\%) of fecal samples and of which 21/36 (58\%) generated positive ribosomal RNA PCRs. The majority of positive samples originated from lambs presenting with diarrhea (19/21) who were between 8 and 21 days of age. PCR RFLP sequence analysis confirmed the presence of two Cryptosporidium species in lambs, including C. parvum in 16/21 (76\%) samples from all studied northern Algerian provinces, and C. ubiquitum in 5/21 (24\%) specimens from northwestern Algeria (the Sidi Bel Abbes province only). Three $C$. parvum subtypes were identified with gp60 gene analysis: IIdA16G1 $(\mathrm{n}=11)$, IIaA13G2R1 $(\mathrm{n}=1)$, and IIaA21G2R1 $(\mathrm{n}=3)$ (Table 1).

\subsection{Giardia duodenalis assemblage occurrence according to age and diarrhea status}

G. duodenalis were detected by IFA in 28\% (23/83) of fecal samples, of which 69\% (16/23) were positive via semi-nested PCR. Three G. duodenalis assemblages were then identified: the ruminant-specific assemblage E (10/16); assemblage A which is infectious for humans and a number of other mammals (livestock, dogs, cats...) (2/16); and assemblage D which has been reported to infect dogs and other canids (4/16). Mixed assemblage A and E infections 
168

were identified in two lambs (2/16). The majority of $g d h$ or tpi PCR products identified mono-infections with ruminant-specific assemblage E. These three assemblages were mainly from non-diarrheic lamb samples (9/16), and were found at a higher rate in older lambs $(>21$ days) than in younger lambs ( $<21$ days).

\section{Discussion}

Cryptosporidium and Giardia species are well-known pathogens of both domesticated farm and companion animals and are thus a significant threat to public health. There is considerable genetic diversity within both Cryptosporidium and Giardia duodenalis, as 14 Cryptosporidium species with several different subtypes, and 6 Giardia species with at least 8 G. duodenalis assemblages have been described (Cacciò et al., 2005). However, little is known about Cryptosporidium and Giardia occurrence rates in small ruminants in Algeria.

This is the first study to identify and perform molecular characterization of Cryptosporidium spp. and G. duodenalis in Algerian lambs, and our analysis revealed a high diversity of Cryptosporidium species and G. duodenlis assemblages within these farm animals.

In this study, IFA was used to screen for the presence of Cryptosporidium oocysts and Giardia cysts prior to performing PCR. In our study, false negative PCRs occurred, indicating that PCR sensitivity was potentially reduced, which could be due to naturally-occuring PCR inhibitors in fecal samples (Yu et al., 2009).

In this study, we report that 27 samples from diarrheal animals were positive for Cryptosporidium, and that 10 diarrheal animal samples were positive for Giardia by immunofluorescence. Most of the cryptosporidiosis-positive samples were collected from young diarrheic lambs, while the majority of Giardia-positive samples were from asymptomatic older animals (Robertson, 2009). This could be due to the fact that 
192

193

194

195

196

197

198

199

200

201

202

203

204

205

206

207

208

209

210

211

212

213

214

with subclinical symptoms. It must be noted that neonatal diarrhea is not necessarily due to Cryptosporidium presence, as other diarrhea-causing pathogens (salmonella, viruses, coccidia...) were not investigated in this study.

The two Cryptosporidium species (C. parvum and C. ubiquitum) identified in the present study, have previously been reported in small ruminants from Algeria (Baroudi et al., 2018) and from other countries (Paraud and Chartier, 2012). In this work, C. parvum was the dominant species (in 16/21 animals, compared to 5/21 with C. ubiquitum), comparable to previous small ruminant data (Drumo et al., 2012; Goma et al., 2007; Maurya et al., 2013; Mueller-Doblies et al., 2008; Quilez et al., 2008; Tzanidakis et al., 2014). The C. xiaoi species was not identified in lambs in the current study, even though it was recently reported to be frequent in small ruminants from Algeria (Baroudi et al., 2018) and other locations (African countries, Asian countries, and some European countries such as Norway and Poland) (Kaupke et al., 2017; Parsons et al., 2015; Peng et al., 2016; Robertson, 2009).

In this study, the dominant $C$. parvum isolate subtype present in the lambs was IIdA16G1 ( $\mathrm{n}=11 / 16)$, while subtypes IIaA21G2R1 $(\mathrm{n}=3 / 16)$ and IIaA13G2R1 $(\mathrm{n}=1 / 16)$ were reported at lower rates. Our results are consistent with multiple other studies, where the $C$. parvum IId subtype family is dominant in countries such as Spain, Romania, and Australia (Díaz et al., 2015; Imre et al., 2013; Quilez et al., 2008; Yang et al., 2014). However in other countries (the UK, Poland, New Guinea) IIa subtype families are dominant (Connelly et al., 2013; Kaupke et al., 2017; Koinari et al., 2014). The identified subtypes pose a real risk to public health, as the IIdA16G1 C. parvum subtype was recently identified in calves and human children from rural regions of northern Tunisia near Algerian borders (Rahmouni et al., 2014), and human Cryptosporidium infections-including subtype IIaA13G2R1-have been 
215

216

217

218

219

220

221

reported in immunosuppressed individuals from Malaysia and Ethiopia (Adamu et al., 2014; Iqbal et al., 2012).

The G. duodenalis assemblages identified in this study indicated that lambs mainly carried G. duodenalis assemblage E mono-infections (10/16), which is usually found in hoofed animals, including cattle and small ruminants (Geurden et al., 2008; Paz e Silva et al., 2014; Tzanidakis et al., 2014). In addition, mixed assemblage A + E infections were identified in two lambs (2/16), similar to reports of zoonotic A + B assemblages in the USA and Australia (Santín et al., 2007; Yang et al., 2014).

Interestingly, and to the best of our knowledge, this is the first description of assemblage D in lambs, which has previously only been identified in dog or canids (Thompson, 2004). This assemblage was isolated from a single extensively-farmed herd where working dogs, stray dogs, and other wild canids are numerous. These animals could contaminate the environment (water and pasture) with Giardia cysts, and thus indirectly contaminate the lambs. Of note, it has been reported that intensive contact between dogs and other animals (pigs and other wild animals) could lead to assemblage D transmission (Ryan and Cacciò, 2013; Sprong et al., 2009). Other large-scale studies are needed to better understand Giardia circulation, particularly of those assemblages not well adapted to ruminants.

Zoonotic pathogenic C. parvum and G. duodenalis subtypes are reported to be common in dairy farm calves from the Algiers region (Baroudi et al., 2017). Our results suggest that lambs may thus be an important reservoir for G. duodenalis in Algeria. Further investigations are required to determine whether this observation holds true in other parts of the country, preferably with larger sample sizes to better understand the epidemiology of cryptosporidiosis and giardiosis in lambs. 
252 Not applicable.

\section{Conflict of interest}

254 The authors declare that they have no conflicts of interest.

\section{References}

256 Adamu, H., Petros, B., Zhang, G., Kassa, H., Amer, S., Ye, J., Feng, Y., Xiao, L., 2014.

257 Distribution and clinical manifestations of Cryptosporidium species and subtypes in 258 HIV/AIDS patients in Ethiopia. PLoS Negl. Trop. Dis. 8, e2831. 259 https://doi.org/10.1371/journal.pntd.0002831 
Ballweber, L.R., Xiao, L., Bowman, D.D., Kahn, G., Cama, V.A., 2010. Giardiasis in dogs and cats: update on epidemiology and public health significance. Trends Parasitol. 26, 180189. https://doi.org/10.1016/j.pt.2010.02.005

Baroudi, D., Hakem, A., Adamu, H., Amer, S., Khelef, D., Adjou, K., Dahmani, H., Chen, X., Roellig, D., Feng, Y., Xiao, L., 2018. Zoonotic Cryptosporidium species and subtypes in lambs and goat kids in Algeria. Parasit. Vectors 11, 582. https://doi.org/10.1186/s13071-018$3172-2$

Baroudi, D., Khelef, D., Hakem, A., Abdelaziz, A., Chen, X., Lysen, C., Roellig, D., Xiao, L., 2017. Molecular characterization of zoonotic pathogens Cryptosporidium spp., Giardia duodenalis and Enterocytozoon bieneusi in calves in Algeria. Vet. Parasitol. Reg. Stud. Rep. 8, 66-69. https://doi.org/10.1016/j.vprsr.2017.02.005

Benhouda, D., Hakem, A., Sannella, A.R., Benhouda, A., Cacciò, S.M., 2017. First molecular investigation of Cryptosporidium spp. in young calves in Algeria. Parasite Paris Fr. 24, 15. https://doi.org/10.1051/parasite/2017014

Bornay-Llinares, F.J., da Silva, A.J., Moura, I.N., Myjak, P., Pietkiewicz, H., KruminisLozowska, W., Graczyk, T.K., Pieniazek, N.J., 1999. Identification of Cryptosporidium felis in a cow by morphologic and molecular methods. Appl. Environ. Microbiol. 65, 1455-1458.

Cacciò, S.M., Thompson, R.C.A., McLauchlin, J., Smith, H.V., 2005. Unravelling Cryptosporidium and Giardia epidemiology. Trends Parasitol. 21, 430-437. https://doi.org/10.1016/j.pt.2005.06.013

Castro-Hermida, J.A., Pors, I., Poupin, B., Ares-Mazás, E., Chartier, C., 2005. Prevalence of Giardia duodenalis and Cryptosporidium parvum in goat kids in western France. Small Rumin. Res. 56, 259-264. https://doi.org/10.1016/j.smallrumres.2004.06.007 
Connelly, L., Craig, B.H., Jones, B., Alexander, C.L., 2013. Genetic diversity of Cryptosporidium spp. within a remote population of Soay Sheep on St. Kilda Islands, Scotland. Appl. Environ. Microbiol. 79, 2240-2246. https://doi.org/10.1128/AEM.02823-12

de Graaf, D.C., Vanopdenbosch, E., Ortega-Mora, L.M., Abbassi, H., Peeters, J.E., 1999. A review of the importance of cryptosporidiosis in farm animals. Int. J. Parasitol. 29, 12691287.

Díaz, P., Quílez, J., Prieto, A., Navarro, E., Pérez-Creo, A., Fernández, G., Panadero, R., López, C., Díez-Baños, P., Morrondo, P., 2015. Cryptosporidium species and subtype analysis in diarrhoeic pre-weaned lambs and goat kids from north-western Spain. Parasitol. Res. 114, 4099-4105. https://doi.org/10.1007/s00436-015-4639-0

Drumo, R., Widmer, G., Morrison, L.J., Tait, A., Grelloni, V., D’Avino, N., Pozio, E., Cacciò, S.M., 2012. Evidence of Host-Associated Populations of Cryptosporidium parvum in Italy. Appl. Environ. Microbiol. 78, 3523-3529. https://doi.org/10.1128/AEM.07686-11

Feng, Y., Ortega, Y., He, G., Das, P., Xu, M., Zhang, X., Fayer, R., Gatei, W., Cama, V., Xiao, L., 2007. Wide geographic distribution of Cryptosporidium bovis and the deer-like genotype in bovines. Vet. Parasitol. 144, 1-9. https://doi.org/10.1016/j.vetpar.2006.10.001

Gatei, W., Hart, C.A., Gilman, R.H., Das, P., Cama, V., Xiao, L., 2006. Development of a multilocus sequence typing tool for Cryptosporidium hominis. J. Eukaryot. Microbiol. 53 Suppl 1, S43-48. https://doi.org/10.1111/j.1550-7408.2006.00169.x

Geurden, T., Thomas, P., Casaert, S., Vercruysse, J., Claerebout, E., 2008. Prevalence and molecular characterisation of Cryptosporidium and Giardia in lambs and goat kids in Belgium. Vet. Parasitol. 155, 142-145. https://doi.org/10.1016/j.vetpar.2008.05.002 
Goma, F., Geurden, T., Siwila, J., Phiri, I., Gabriël, S., Claerebout, E., Vercruysse, J., 2007. The prevalence and molecular characterisation of Cryptosporidium spp. in small ruminants in Zambia. SMALL Rumin. Res. 72, 77-80.

Imre, K., Luca, C., Costache, M., Sala, C., Morar, A., Morariu, S., Ilie, M.S., Imre, M., Dărăbuş, G., 2013. Zoonotic Cryptosporidium parvum in Romanian newborn lambs (Ovis aries). Vet. Parasitol. 191, 119-122. https://doi.org/10.1016/j.vetpar.2012.08.020

Iqbal, A., Lim, Y.A.L., Surin, J., Sim, B.L.H., 2012. High diversity of Cryptosporidium subgenotypes identified in Malaysian HIV/AIDS individuals targeting gp60 gene. PloS One 7, e31139. https://doi.org/10.1371/journal.pone.0031139

Kaupke, A., Michalski, M.M., Rzeżutka, A., 2017. Diversity of Cryptosporidium species occurring in sheep and goat breeds reared in Poland. Parasitol. Res. 116, 871-879. https://doi.org/10.1007/s00436-016-5360-3

Koinari, M., Lymbery, A.J., Ryan, U.M., 2014. Cryptosporidium species in sheep and goats from Papua New Guinea. Exp. Parasitol. 141, 134-137. https://doi.org/10.1016/j.exppara.2014.03.021

Maurya, P.S., Rakesh, R.L., Pradeep, B., Kumar, S., Kundu, K., Garg, R., Ram, H., Kumar, A., Banerjee, P.S., 2013. Prevalence and risk factors associated with Cryptosporidium spp. infection in young domestic livestock in India. Trop. Anim. Health Prod. 45, 941-946. https://doi.org/10.1007/s11250-012-0311-1

Mueller-Doblies, D., Giles, M., Elwin, K., Smith, R.P., Clifton-Hadley, F.A., Chalmers, R.M., 2008. Distribution of Cryptosporidium species in sheep in the UK. Vet. Parasitol. 154, 214-219. https://doi.org/10.1016/j.vetpar.2008.03.021 
327

Ouakli, N., Belkhiri, A., de Lucio, A., Köster, P.C., Djoudi, M., Dadda, A., Khelef, D., Kaidi, R., Carmena, D., 2018. Cryptosporidium-associated diarrhoea in neonatal calves in Algeria. Vet. Parasitol. Reg. Stud. Rep. 12, 78-84. https://doi.org/10.1016/j.vprsr.2018.02.005

Paraud, C., Chartier, C., 2012. Cryptosporidiosis in small ruminants. Small Rumin. Res., Special issue: Specificities of parasitism in goats and sheep: interactions with nutrition and control strategies 103, 93-97. https://doi.org/10.1016/j.smallrumres.2011.10.023

Parsons, M.B., Travis, D., Lonsdorf, E.V., Lipende, I., Roellig, D.M., Roellig, D.M.A., Collins, A., Kamenya, S., Zhang, H., Xiao, L., Gillespie, T.R., 2015. Epidemiology and molecular characterization of Cryptosporidium spp. in humans, wild primates, and domesticated animals in the Greater Gombe Ecosystem, Tanzania. PLoS Negl. Trop. Dis. 9, e0003529. https://doi.org/10.1371/journal.pntd.0003529

Paz e Silva, F.M., Lopes, R.S., Bresciani, K.D.S., Amarante, A.F.T., Araujo, J.P., 2014. High occurrence of Cryptosporidium ubiquitum and Giardia duodenalis genotype $\mathrm{E}$ in sheep from Brazil. Acta Parasitol. 59, 193-196. https://doi.org/10.2478/s11686-014-0223-5

Peng, X.-Q., Tian, G.-R., Ren, G.-J., Yu, Z.-Q., Lok, J.B., Zhang, L.-X., Wang, X.-T., Song, J.-K., Zhao, G.-H., 2016. Infection rate of Giardia duodenalis, Cryptosporidium spp. and Enterocytozoon bieneusi in cashmere, dairy and meat goats in China. Infect. Genet. Evol. J. Mol. Epidemiol. Evol. Genet. Infect. Dis. 41, 26-31. https://doi.org/10.1016/j.meegid.2016.03.021

Quilez, J., Torres, E., Chalmers, R.M., Hadfield, S.J., del Cacho, E., Sanchez-Acedo, C., 2008. Cryptosporidium Genotypes and Subtypes in Lambs and Goat Kids in Spain. Appl. Environ. Microbiol. 74, 6026-6031. https://doi.org/10.1128/AEM.00606-08 
Rahmouni, I., Essid, R., Aoun, K., Bouratbine, A., 2014. Glycoprotein 60 diversity in Cryptosporidium parvum causing human and cattle cryptosporidiosis in the rural region of Northern Tunisia. Am. J. Trop. Med. Hyg. 90, 346-350. https://doi.org/10.4269/ajtmh.130522

Read, C.M., Monis, P.T., Thompson, R.C.A., 2004. Discrimination of all genotypes of Giardia duodenalis at the glutamate dehydrogenase locus using PCR-RFLP. Infect. Genet. Evol. J. Mol. Epidemiol. Evol. Genet. Infect. Dis. 4, 125-130. https://doi.org/10.1016/j.meegid.2004.02.001

Robertson, L.J., 2009. Giardia and Cryptosporidium infections in sheep and goats: a review of the potential for transmission to humans via environmental contamination. Epidemiol. Infect. 137, 913-921. https://doi.org/10.1017/S0950268809002295

Ryan, U., Cacciò, S.M., 2013. Zoonotic potential of Giardia. Int. J. Parasitol. 43, 943-956. https://doi.org/10.1016/j.ijpara.2013.06.001

Santín, M., Trout, J.M., Fayer, R., 2007. Prevalence and molecular characterization of Cryptosporidium and Giardia species and genotypes in sheep in Maryland. Vet. Parasitol. 146, 17-24. https://doi.org/10.1016/j.vetpar.2007.01.010

Sprong, H., Cacciò, S.M., van der Giessen, J.W.B., ZOOPNET network and partners, 2009. Identification of zoonotic genotypes of Giardia duodenalis. PLoS Negl. Trop. Dis. 3, e558. https://doi.org/10.1371/journal.pntd.0000558

Sulaiman, I.M., Fayer, R., Bern, C., Gilman, R.H., Trout, J.M., Schantz, P.M., Das, P., Lal, A.A., Xiao, L., 2003. Triosephosphate isomerase gene characterization and potential zoonotic transmission of Giardia duodenalis. Emerg. Infect. Dis. 9, 1444-1452. https://doi.org/10.3201/eid0911.030084 
372

Sulaiman, I.M., Hira, P.R., Zhou, L., Al-Ali, F.M., Al-Shelahi, F.A., Shweiki, H.M., Iqbal, J., Khalid, N., Xiao, L., 2005. Unique Endemicity of Cryptosporidiosis in Children in Kuwait. J. Clin. Microbiol. 43, 2805-2809. https://doi.org/10.1128/JCM.43.6.2805-2809.2005

Thompson, R.C.A., 2004. The zoonotic significance and molecular epidemiology of Giardia and giardiasis. Vet. Parasitol. 126, 15-35. https://doi.org/10.1016/j.vetpar.2004.09.008

Tzanidakis, N., Sotiraki, S., Claerebout, E., Ehsan, A., Voutzourakis, N., Kostopoulou, D., Stijn, C., Vercruysse, J., Geurden, T., 2014. Occurrence and molecular characterization of Giardia duodenalis and Cryptosporidium spp. in sheep and goats reared under dairy husbandry systems in Greece. Parasite Paris Fr. $21,45$. https://doi.org/10.1051/parasite/2014048

Xiao, L., 2010. Molecular epidemiology of cryptosporidiosis: An update. Exp. Parasitol., Cryptosporidium and other waterborne protozoa $124, \quad 80-89$. https://doi.org/10.1016/j.exppara.2009.03.018

Xiao, L., Morgan, U.M., Limor, J., Escalante, A., Arrowood, M., Shulaw, W., Thompson, R.C.A., Fayer, R., Lal, A.A., 1999. Genetic Diversity within Cryptosporidium parvum and Related Cryptosporidium Species. Appl. Environ. Microbiol. 65, 3386-3391.

Yang, R., Jacobson, C., Gardner, G., Carmichael, I., Campbell, A.J.D., Ng-Hublin, J., Ryan, U., 2014. Longitudinal prevalence, oocyst shedding and molecular characterisation of Cryptosporidium species in sheep across four states in Australia. Vet. Parasitol. 200, 50-58. https://doi.org/10.1016/j.vetpar.2013.11.014

Yu, J.-R., Lee, S.-U., Park, W.-Y., 2009. Comparative Sensitivity of PCR Primer Sets for Detection of Cryptosporidium parvum. Korean J. Parasitol. 47, 293-297. https://doi.org/10.3347/kjp.2009.47.3.293 
Figure 1. Map of Algeria indicating the location, geographical distribution, and number of sheep farms investigated in this study (Djelfa, Msila, Sidi Bel Abbès, and Souk Ahras provinces).

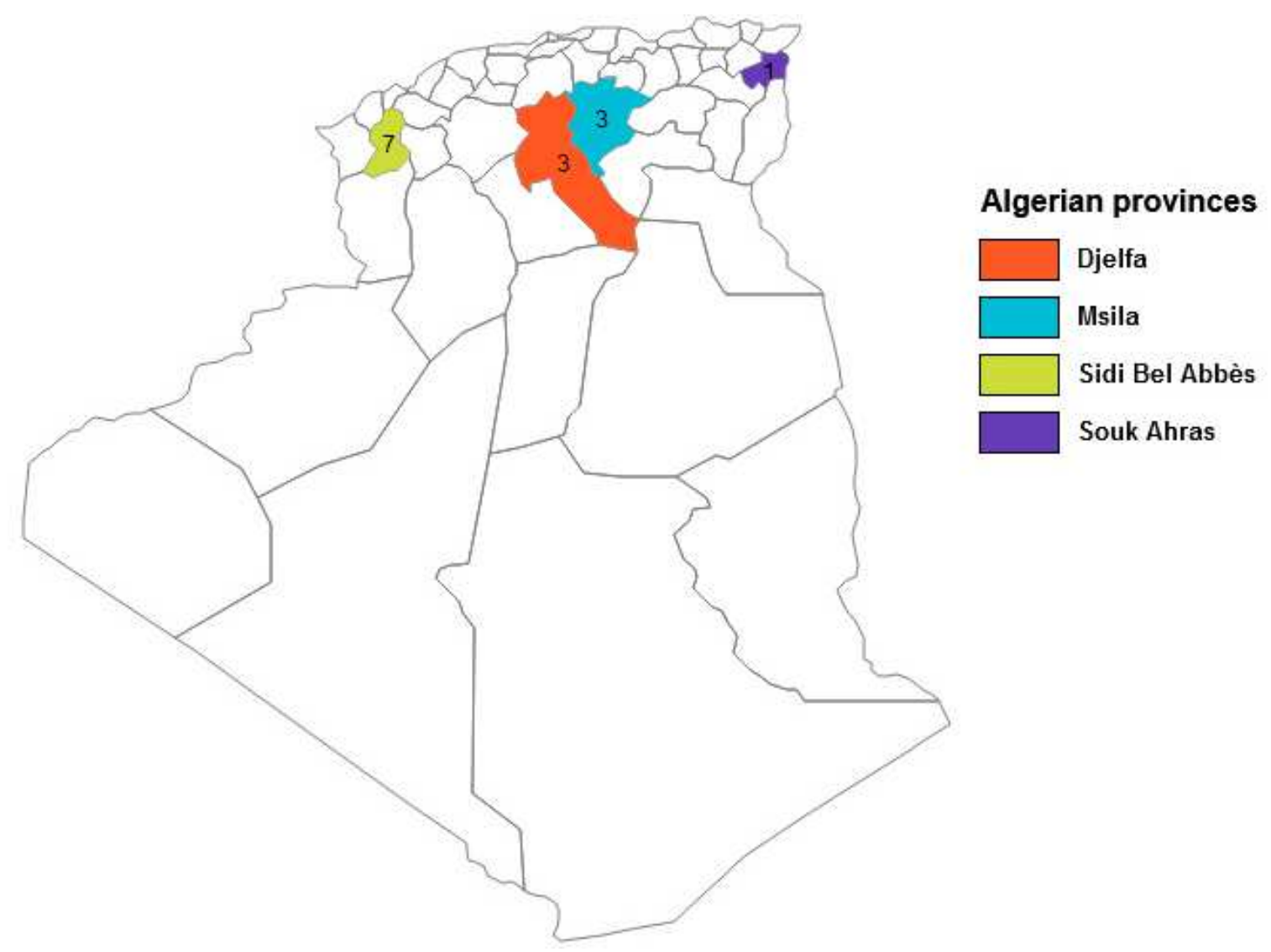


Tables

Table 1. Occurrence of Cryptosporidium species and Giardia assemblages in lambs from Djelfa, Msila, Sidi Bel Abbès and Souk Ahras provinces, Algeria.

\begin{tabular}{|c|c|c|c|c|c|c|c|c|c|c|c|c|c|}
\hline \multirow[t]{2}{*}{ Farm locations } & \multirow{2}{*}{$\begin{array}{l}\text { No. of } \\
\text { farms }\end{array}$} & \multirow{2}{*}{$\begin{array}{l}\text { Extensive } \\
\text { farms }\end{array}$} & \multirow{2}{*}{$\begin{array}{l}\text { Intensive } \\
\text { farms }\end{array}$} & \multirow{2}{*}{$\begin{array}{l}\text { No. of } \\
\text { samples } \\
\text { tested }\end{array}$} & \multicolumn{5}{|c|}{ Cryptosporidium spp. } & \multicolumn{4}{|c|}{ Giardia duodenalis } \\
\hline & & & & & $\begin{array}{l}\text { No. of } \\
\text { Cryptosporidium } \\
\text { positive samples } \\
\text { via IF (Farms } \\
\text { indicated) }\end{array}$ & $\begin{array}{l}\text { No. of IFA- } \\
\text { positive } \\
\text { samples } \\
\text { from } \\
\text { diarrheic } \\
\text { lambs }\end{array}$ & $\begin{array}{l}\text { No. of } \\
\text { Cryptosporidium- } \\
\text { positive samples } \\
\text { via PCR }\end{array}$ & $\begin{array}{l}\text { Cryptosporidium } \\
\text { species }\end{array}$ & $\begin{array}{l}\text { C. parvum } \\
\text { subtypes } \\
\text { (No. /Total) }\end{array}$ & $\begin{array}{l}\text { No. of } \\
\text { Giardia } \\
\text { positive } \\
\text { samples via } \\
\text { IF (Farms } \\
\text { indicated) }\end{array}$ & $\begin{array}{l}\text { No. of IFA- } \\
\text { positive } \\
\text { samples from } \\
\text { diarrheic } \\
\text { lambs }\end{array}$ & $\begin{array}{l}\text { No. of } \\
\text { Giardia- } \\
\text { positive } \\
\text { samples via } \\
\text { PCR }\end{array}$ & $\begin{array}{l}\text { Giardia } \\
\text { assemblages } \\
\text { (No./Total) }\end{array}$ \\
\hline \multirow[t]{3}{*}{ Djelfa } & \multirow[t]{3}{*}{3} & \multirow[t]{3}{*}{ *F9 } & \multirow[t]{3}{*}{ F10, F11 } & \multirow[t]{3}{*}{24} & \multirow[t]{3}{*}{$7(\mathrm{Fg}, \mathrm{F} 10, \mathrm{~F} 11)$} & \multirow[t]{3}{*}{3} & \multirow[t]{3}{*}{3} & \multirow[t]{3}{*}{ C. parvum (3) } & IlaA13G2R1(1/3) & \multirow[t]{3}{*}{7 (F9, F11) } & \multirow[t]{3}{*}{0} & \multirow[t]{3}{*}{4} & $E(2 / 4)$ \\
\hline & & & & & & & & & & & & & $\mathrm{D}(1 / 4)$ \\
\hline & & & & & & & & & IIdA16G1 (2/3) & & & & $A+E(1 / 4)$ \\
\hline Msila & 3 & F12 & F13, F14 & 17 & 4 (F12,F14) & 4 & 4 & C. parvum (4) & IIdA16G1 (3/4) & 2 (F12, F13) & 0 & 2 & $E(2 / 2)$ \\
\hline \multirow[t]{3}{*}{ Sidi Bel Abbès } & \multirow[t]{3}{*}{7} & \multirow{3}{*}{$\begin{array}{l}\text { F3, F4, } \\
\text { F5, F6, } \\
\text { F7, F8 }\end{array}$} & \multirow[t]{3}{*}{ F2 } & \multirow[t]{3}{*}{37} & \multirow{3}{*}{$\begin{array}{l}22 \\
(F 2, F 4, F 5, F 6, F 7, F 8\end{array}$} & \multirow[t]{3}{*}{17} & \multirow[t]{3}{*}{11} & C. parvum (6) & IIdA16G1 (6/6) & \multirow{3}{*}{$\begin{array}{l}14 \text { (F2, } \\
\text { F3,F4, F5, } \\
F 7, F 8)\end{array}$} & \multirow[t]{3}{*}{10} & \multirow[t]{3}{*}{10} & $E(6 / 10)$ \\
\hline & & & & & & & & & & & & & $\mathrm{D}(3 / 10)$ \\
\hline & & & & & & & & C. ubiquitum (5) & - & & & & $A+E(1 / 10)$ \\
\hline Souk Ahras & 1 & F1 & - & 5 & 3 (F1) & 3 & 3 & C. parvum (3) & IlaA21G2R1(3/3) & 0 & 0 & 0 & - \\
\hline Total & 14 & 9 & 5 & 83 & 36 & 27 & 21 & 2 species & 3 subtypes & 23 & 10 & 16 & 3 assemblages \\
\hline
\end{tabular}

*F: Farms included in this study were arbitrarily designated from F1 to F14. 